\title{
Editorial RealizAção: trilhando os caminhos da Sustentabilidade através da Justiça Social, Viabilidade Econômica e Responsabilidade Ambiental
}

\author{
Emerson Machado de Carvalho ${ }^{1}$ \\ Juliana Rosa Carrijo Mauad ${ }^{2}$ \\ Rosilda Mara Mussury ${ }^{3}$ \\ Gicelma da Fonseca Chacarosqui Torchi ${ }^{4}$
}

Neste quarto volume, número sete, a RealizAção - Revista Online de Extensão

e Cultura, tem como objetivo tornar público as reflexões e resultados de ações de extensão desenvolvidas no âmbito local, regional, nacional e internacional, em rede de atores e instituições sociais. A revista é editada pela Pró-Reitoria de Extensão e Cultura da Universidade Federal da Grande Dourados - PROEX/UFGD em periodicidade semestral.

A Revista RealizAçao está publicando trabalhos nas áreas temáticas de Comunicação, Cultura, Direitos Humanos, Educação, Meio Ambiente, Saúde, Tecnologia e Produção, Trabalho, Geração de Trabalho e Renda, Gênero, Economia Solidária, Igualdade Racial, Diversidade Étnica, Juventude e Terceira Idade. Em cada número serão publicados o mínimo de oito trabalhos, entre artigos, resenhas, relatos de experiências, que poderão ser apresentados nos idiomas português, espanhol e inglês. A seleção será realizada por meio Edital de Fluxo Contínuo, e avaliado por pares: profissionais com experiência em Extensão Universitária.

Os trabalhos encaminhados para esta edição foram avaliados pelo Conselho Editorial e por consultores ad hoc. No processo de seleção foram observados os seguintes critérios: prioridade do tema, consistência científica, originalidade, atualidade da informação, atendimento das normas éticas e técnicas, bem como impacto social das informações.

A Realização apresenta nesta edição oito trabalhos, entre artigos e relatos de experiências em extensão e cultura em diferentes áreas do conhecimento. É possível destacar as áreas de Educação Inclusiva, Economia Social, Economia Solidária, Direito e Segurança do Trabalho. Estes trabalhos buscam apontar caminhos Sustentáveis

\footnotetext{
${ }^{1}$ Editor Chefe da Realização - Revista Online de Extensão e Cultura.

${ }^{2}$ Pró-reitora da PROEX - Pró-reitoria de Extensão e Cultura.

${ }^{3}$ Coordenadora de Extensão - PROEX.

${ }^{4}$ Coordenadora de Cultura - PROEX. 
através da Justiça Social, Viabilidade Econômica e Responsabilidade Ambiental. Um breve relato dos trabalhos pode ser apreciado na sequência.

O relato de experiência: "Metodologias ativas de ensino e aprendizagem: uma experiência com docentes da educação básica", autoria de Antônio Eustáquio Ferreira, descreve a experiência de um curso de formação continuada de professores, desenvolvido em parceria com a Universidade Federal da Grande Dourados, sob a coordenação e execução do autor.

$\mathrm{O}$ artigo: "Análise do direito criminal e penal quanto as penalidades indenizatórias na questão ambiental sob a ótica do mainstream econômico", autoria de José Cordeiro Neto, Luanne Escobar do Nascimento Oliveira e Luciana Ferreira da Silva, buscou através de pesquisas, informações a respeito do atual contexto ambiental brasileiro de como a lei interpreta os fatos e quais as penalidades indenizatórias sob a ótica do Mainstream Econômico. O intuito é verificar quais pontos positivos e negativos relacionados ao que vem sendo produzido a respeito do assunto pelos doutrinadores, legisladores e ainda pela jurisprudência.

O relato de experiência: “Apicultura na comunidade Areias em sistemas agroecológicos e de produção orgânica", autoria de Elaine Barbosa Muniz e colaboradores, compartilham os resultados obtidos com o projeto de extensão: "Sistema orgânico e agroecológico de criação de abelhas na comunidade Areias" desenvolvido junto a PROEX/UFGD, no assentamento localizado no Município de Nioaque, MS. O enfoque da ação esteve direcionado nas técnicas de manejo com abelhas, para a produção do mel, que fossem apropriadas para o êxito da atividade naquela região, lugar de área pantaneira.

O artigo: "Programa de Aquisição de Alimentos em MS: soberania alimentar, crise e perspectivas de superação" de Carlos Alberto Heling e colaboradores destacam a importância do PAA (Programa de Aquisição de Alimentos) para Agricultura Familiar. Os autores destacam a problemática envolvida por parte da atual gestão do Governo Federal e consequentemente no estado de Mato Grosso do Sul (MS), no que se refere ao contingenciamento orçamentário e a diminuição do alcance dos objetivos básicos originários do programa.

No artigo: "Um breve olhar sobre a autonomia de jovens universitários em Campo Grande no período de 2012 a 2017", de autoria de Priscila Palhanos e Heitor Romero Marques, é relatado as formas de organização de estudantes universitários que não vivem com os pais em Campo Grande, no período de 2012 a 2017. Objetivou-se 
com este resultado investigar como esses jovens se relacionam, quais estruturas desenvolveram - ou não - de autonomia para que possam iniciar a fase adulta em termos sociopsicológicos.

O artigo: "Assédio moral: seus impactos para os trabalhadores assediados e para os empregadores no Brasil", de autoria de Arthur Ramos do Nascimento e José Cordeiro Neto, demonstra que a prática do Assédio Moral acarreta impactos para as organizações. Entre elas, destaca-se as indenizações por danos morais, imagem da organização exposta na mídia, e problemas de saúde para a vítima. Possuindo uma pesquisa bibliográfica, o presente artigo abordou o tipo de assédio moral mais comum que é o Assédio Vertical Descendente, e formas de reparação dos danos causados por suas práticas às vítimas.

No artigo: "Ilustração científica: os caminhos entre a arte e a ciência", autoria de Nathaskia Silva Pereira e colaboradores, foi abordado a importância da ilustração científica tanto para formação científica do ilustrador como para o desenvolvimento de habilidades visuais e manuais por parte do taxonomista. Os autores argumentam que a técnica de ilustração científica nem sempre é uma prática comum entre os pesquisadores, precisando do auxílio de um ilustrador de outras áreas.

No artigo: "Avaliação de riscos ergonômicos durante o trabalho odontológico: um estudo de caso", autoria de Luis Cesar Giansante Tonello e Emerson Machado de Carvalho, foi analisada a percepção e o discurso sobre ergonomia, bem como os principais problemas de postura durante o atendimento odontológico de um cirurgião dentista. De acordo com as observações dos autores, muitas vezes, o profissional se esquece dos princípios ergonômicos e acaba adotando posturas inadequadas e de risco para sua saúde.

Assim, colocamos a disposição o volume 4, número 7, da Realização - Revista Online de Extensão e Cultura, ano de 2017. 